Georgia State University

ScholarWorks @ Georgia State University

$12-2013$

\title{
Sexual Orientation, Work Values, Pay, and Preference for Public and Nonprofit Employment: Evidence from Canadian Postsecondary Students
}

\author{
Gregory B. Lewis \\ Georgia State University, glewis@gsu.edu \\ Eddy $\mathrm{Ng}$ \\ Dalhousie University, edng@dal.ca
}

Follow this and additional works at: https://scholarworks.gsu.edu/pmap_facpubs

Part of the Public Affairs, Public Policy and Public Administration Commons

\section{Recommended Citation}

Lewis, Gregory B. and Ng, Eddy, "Sexual Orientation, Work Values, Pay, and Preference for Public and Nonprofit Employment: Evidence from Canadian Postsecondary Students" (2013). PMAP Publications. 6. https://scholarworks.gsu.edu/pmap_facpubs/6

This Article is brought to you for free and open access by the Department of Public Management and Policy at ScholarWorks@ Georgia State University. It has been accepted for inclusion in PMAP Publications by an authorized administrator of ScholarWorks @ Georgia State University. For more information, please contact scholarworks@gsu.edu. 


\title{
Sexual Orientation, Work Values, Pay, and \\ Preference for Public and Nonprofit Employment: \\ Evidence from Canadian Postsecondary Students
}

\begin{abstract}
Despite some evidence that gay men hold fewer government jobs in the U.S. than their population share would predict, analysis of two large surveys of Canadian university and college students shows no lack desire for public sector jobs among GLBTQs. Instead, we find that (1) GLBTQs are more likely than heterosexuals to prefer public and nonprofit sector employment; (2) GLBTQ career goals and work values predict a stronger desire for public and nonprofit sector jobs than do those of heterosexuals; and (3) GLBTQs expect to pay a smaller penalty for working in the public and nonprofit sectors. In partial support of public service motivation theory, we find that altruistic motives drive students to both the public and the nonprofit sectors (though desires for job security and strong health and benefit plans have a bigger impact on wanting a government job). Despite economists' findings that the federal government pays comparable workers more than the private sector, students preparing for government jobs expect to earn less than those heading to the private sector, and students who prioritize starting salary and advancement opportunities prefer private sector jobs.
\end{abstract}




\section{Sexual Orientation, Work Values, Pay, and \\ Preference for Public and Nonprofit Employment: \\ Evidence from Canadian Postsecondary Students}

As a stigmatized minority, GLBTQs (gays, lesbians, bisexuals, transgenders, and queers ${ }^{1}$ ) have struggled for decades to strengthen their voice in government. One path to policy impact that particularly interests scholars of public administration is public employment, as minority representation in the workforce can increase the quality of services government provides to minorities. Government jobs also reward workers in a variety of ways, including middle-class pay, job security, pensions, health insurance, and the opportunity to be useful to society.

GLBTQs have historically faced obstacles to full representation in both the U.S. and Canadian public service. Partnered gay men remain under-represented in U.S. governments, perhaps due to systemic or lingering personal discrimination, but perhaps also due to GLBTQs' preferences, because their career goals and work values do not align well with public service or because they expect more discrimination in the public sector. We don't know whether GLBTQs are also under-represented in the Canadian public service, but we can test whether GLBTQs' values and perceptions pose an obstacle to government employment.

Using two large surveys of potential future government employees (university and college students), we address three questions: (1) Do GLBTQs and heterosexuals differ in their preferences for public, nonprofit, and private sector employment? (2) Do GLBTQ-heterosexual differences in career goals and work values explain differences in their preferred sectors of employment? (3) Do GLBTQs expect more discrimination in the public sector? We find that

\footnotetext{
${ }^{1}$ This is the wording used in the surveys.
} 
GLBTQs actually want public and nonprofit sector jobs more than heterosexuals do, that their career goals and work values align better with public and nonprofit jobs than do those of heterosexuals; and that GLBTQs expect less pay discrimination in the public and nonprofit sectors than in the private, for-profit sector. If GLBTQs are under-represented in Canadian governments, lack of desire is not likely to be the explanation.

\section{BACKGROUND}

Although Canada is at the forefront of human rights for GLBTQs today, it has not always protected the interests of gays and lesbians. During the Cold War, partly to appease the Americans and partly to quell fears that homosexuals posed a threat to national security (Kinsman 1995), the Canadian government attempted to root out homosexuals from federal offices, even in offices where security risks were low, such as the Canadian Mortgage and Housing Corporation, the Department of Public Works, and the Unemployment Insurance Commission (Robinson and Kimmel 1994). Even gays and lesbians outside the public service were investigated, because they might later seek government employment. The Royal Canadian Mounted Police, in collaboration with psychologist Robert Wake, invented the 'fruit machine' to detect homosexuality by measuring eye movements of people shown hetero- and homoerotic pictures (Beeby 1992; Kinsman 1995). Government officials referred to gays as practicing criminals because homosexual acts were a crime under the Criminal Code (McLeod 1996).

In 1969, the Liberal government under Prime Minister Pierre Trudeau decriminalized homosexual acts between consenting adults, but it wasn't until 1995 in Egan v. Canada, that sexual orientation was read into the Charter of Rights and Freedom (Wintemute 2003). Other 
important public policy changes in the areas of family and employment law followed, including the addition of sexual orientation to the Canadian Human Rights Act in 1996 (Nierobisz, Searl, and Théroux 2008). However, the federal Employment Equity Act, which prohibits discrimination in access to jobs with the federal government and federally regulated industries, was not extended to GLBTQs. Today, numerous open GLBTQs hold elected office, including openly gay federal cabinet ministers and a provincial premier (Robinson 2013), but as a small minority, GLBTQs lack the political resources to pass legislation promoting their interests without strong allies (Sherrill 1996).

Government employment is one alternative path to policy influence. Bureaucratic discretion means that the values held by public sector workers can influence the quality of services they provide and the groups whose interests they consider in making policy decisions. In the U.S., representative bureaucracy researchers have found that the representation of blacks, Latinos, and women in government affects outcomes for blacks, Latinos, and women in the population (Keiser et al. 2002; Meier 1993; Hindera 1993; Selden 1997; Dolan 2000). As a small minority, GLBTQs will rarely reach a critical mass that some researchers suggest may be necessary for successful active representation (Meier, Wrinkle, and Polinard 1999; Meier 1993), but Lim (2006) and Meier and Nicholson-Crotty (2006) suggest that minority bureaucrats change the behaviour of majority bureaucrats through such means as calling them on inappropriate treatment, causing them to check their own behaviour to avoid disapproval, and eventually re-socializing them into a greater understanding of and sympathy for minority groups. Given strong evidence that knowing someone gay increases support for gay rights 
(Herek and Capitanio 1996; Lewis and Gossett 2008; Lewis 2011; Pettigrew and Tropp 2006), even low levels of LGB representation are likely to facilitate such a socialization process.

In sum, those committed to GLBTQ equality should care about their representation in government workforces. In the U.S., evidence that men with male partners are one-fourth less likely than comparable married men to work for government (Lewis and Pitts 2011) calls for an explanation of that under-representation. Although we have no evidence of similar underrepresentation in Canada, it could exist if two of the possible explanations of the U.S. underrepresentation are true. First, GLBTQs might be less likely to pursue government jobs, due to expectations of greater discrimination in the public sector. In Canada, that could be vestiges of formal discrimination and the lack of affirmative action. Second, GLBTQs' career goals and work values might not be a good match with government jobs.

Strong research traditions in both public administration and nonprofit studies emphasize the importance of altruism or public service motivation (PSM) in choosing to work for governments or nonprofit organizations. A substantial literature addresses the impact of PSM on seeking or keeping government jobs (Perry and Wise 1990; Perry, Hondeghem, and Wise 2010; Crewson 1997; Rainey 1982; Karl and Sutton 1998; Kilpatrick, Cummings, and Jennings 1964; Vandenabeele 2008; Christensen and Wright 2011; Wright 2007; Taylor 2008; Steijn 2008). Scholars of the nonprofit sector emphasize "donative labor," that is, that nonprofit workers - especially managers and professionals - donate part of their labor by working for below-market pay (Weisbrod 1983; Preston 1990, 1989; Rose-Ackerman 1996; Hansmann 1980; Frank 1996), at least partly because many people find nonprofit work more 
socially responsible, meaningful, and personally rewarding than for-profit or government employment (Mirvis 1992; Mirvis and Hackett 1983; Frank 1996; Light 2002).

Economists are skeptical of altruism claims, especially as they doubt that nonprofit and, especially, public sector pay is low enough to require special explanations for choosing employment in either sector. In the U.S., although Bureau of Labor Statistics surveys indicate that the federal government currently pays at least 36 percent less than the private sector pay for similar jobs (President's Pay Agent 2011), economists find that similar workers (typically, equally educated and experienced workers of the same race and sex) earn much more in the federal government than in the private sector (Smith 1976a; Gyourko and Tracy 1988; Belman and Heywood 1989; Moulton 1990). Findings are mixed for the nonprofit sector, with some studies finding no major pay differences between the nonprofit and private sectors (Goddeeris 1988; Ruhm and Borkoski 2003), or at least that the nonprofit pay disadvantage is disappearing (Leete 2001). Research on sectoral pay differences in Canada is more limited but generally finds that the federal government pays more than the private sector for similar workers, except at upper levels; evidence is more mixed for provincial and local government pay (Mueller 1998, 2000).

An alternative research tradition emphasizes the importance of job security and benefits in attracting workers to the public sector. Layoffs are far less common in government jobs, and civil service protections make dismissals more difficult. Several studies confirm that the public sector is more attractive to security-seeking employees (Baldwin 1991; Bellante and Link 1981; Kilpatrick, Cummings, and Jennings 1964; Houston 2000; Lewis and Frank 2002), though others disagree (Newstrom, Reif, and Monczka 1976; Karl and Sutton 1998; Rainey 1982; Wittmer 
1991). Little is known about the impact of a desire for job security on choice of nonprofit jobs, but job security has generally been low in the sector (Mirvis 1992; Mirvis and Hackett 1983), implying that those who most highly value job security look elsewhere.

Thus, GLBTQ-heterosexual differences in PSM, extrinsic vs. intrinsic motivation, and desire for job security could all lead to differences in preferred sector of employment. One popular stereotype of hedonistic gay men (and perhaps lesbians) free from the demands of raising children might lead one to expect GLBTQs to be less altruistic, more extrinsically oriented, and less interested in job security than heterosexuals. Black, Sanders, and Taylor (2007) provide theoretical and empirical support for the hypothesis that the greater obstacles that GLBTQs face in having children lead them to have different priorities and to spend their time and money differently. GLBTQs' lower probability of having children to support and spouses to negotiate moves with could make job losses less frightening and motivate moves to expensive, "high-amenity" cities like San Francisco (Black et al. 2002).

On the other hand, the absence of children could also make high pay less important, making more intrinsically rewarding work more attractive and affordable. In the U.S., Lewis (2010) finds that a man is more likely to work for a nonprofit if he does not have children and if his spouse/partner earns more. He also finds that partnered gay men are more than twice as likely as married or heterosexually partnered men to work for nonprofits and that women with female partners are 30 percent more likely than married women and nearly twice as likely as heterosexually partnered women to do so (also see Badgett and King 1997). He tentatively attributes some of that pattern to lesbians' and gay men's higher levels of altruism (although he has no direct measure of altruism), because a variety of other explanations explain little of the 
over-representation. Lesbians' and gay men's striking liberalism (Hertzog 1996; Bailey 1999;

Lewis, Rogers, and Sherrill 2011; Egan 2012) should also increase their propensity to seek government jobs, as liberals feel more positively about government and are more likely to want government jobs (Lewis and Frank 2002).

Second, GLBTQs might also avoid government jobs because they fear greater discrimination in the public sector, perhaps because of government's history of explicit bans on employment of GLBTQs. This argument, however, runs counter to research showing the women and minorities are more likely to prefer government jobs (Blank 1985; Lewis and Frank 2002), largely because they expect stronger protection from discrimination in the public sector. Economists typically find that the white male pay advantage over comparable women and minorities is smaller in government than in the private sector (Asher and Popkin 1984; Perloff and Wachter 1984; Smith 1976b; Moore and Raisian 1991). This pattern also appears to hold in Canada (Hou and Coulombe 2010; Mueller 1998, 2000). Although lesbians and especially gay men are frequently depicted as a high disposable income demographic (Badgett 2003; Black et al. 2002), gay men in the U.S. typically earn less than comparable heterosexual men, though patterns are far more mixed for lesbians (Black et al. 2003; Badgett 1995; Allegretto and Arthur 2001; Berg and Lien 2002; Carpenter 2007, 2004). These patterns appear to hold in Canada as well (Carpenter 2008).

In sum, we test whether (1) GLBTQs and heterosexuals differ in their preferences for public, nonprofit, and private sector employment; (2) GLBTQ-heterosexual differences in career goals and work values explain differences in preferred sector of employment; and (3) GLBTQs expect more discrimination in the public sector. 


\section{Data and Method}

Brainstorm and DECODE produce an annual "Top Campus Employers Report" based on surveys of Canadian students. A consortium of large Canadian employers commission the survey to better understand students' views on jobs, careers, and their own organizations. Brainstorm and DECODE distribute the survey to campus career centres of all the postsecondary institutions across the country in the spring. They conduct the survey exclusively online and promote it primarily via direct email and, in some cases, via web links on university or college websites. More than 50 post-secondary institutions actively help promote the survey via email. Students have a chance to win an iPod for participating in the survey.

We use their 2007 survey of 34,000 students at 185 universities and colleges and their 2010 survey of 28,000 students at 226 schools. Because of question changes between the two surveys and survey design decisions not to ask all respondents all questions, we perform analyses on two subsets of the samples. The first section uses 26,000 students from the 2007 wave, which has the best measure of altruism. The second section uses a broader array of work values and combines the 16,000 students who were asked those questions in 2007 with 26,000 respondents from 2010.

Our key dependent variables are responses to the questions: "Which type of organization would you prefer to work for after graduation?" "What annual base salary do you expect at your first job after graduation?" and "What annual base salary do you expect five years after graduation?" We restrict the sample to students who indicated a preference to work for "government/public services," "nonprofit/charity/social enterprise," or small, medium, or large companies (combined into private sector) or to start their own business; we 
dropped those who did not know which sector they preferred. For regression analyses, we used the natural logarithm of expected base salary, which assumes that a one-unit increase in an independent variable has a constant percentage, rather than a constant dollar, impact on earnings.

Our key independent variable comes from responses to the question: "Do you belong to any of the following groups? (Please indicate all that apply.)" The options included "Aboriginal peoples," "Persons with disabilities," "Visible minority," and "Gay, lesbian, bisexual, transgender or queer." We created dummy variables coded 1 for respondents identifying themselves in each group. Because we expect the impact of sexual orientation to be different for men and women, we created separate dummy variables for GLBTQ men and women. About 3 percent of respondents identified as GLBTQ, giving us about 1,000 GLBTQs in each year, though we lose many of them due to missing values on other variables. Given the social stigma GLBTQs face, we can expect some under-reporting, especially as 3.7 percent chose "I don't wish to say" in response to this set of questions. We created a separate dummy variable for them, so that our reference group is students who say they are heterosexual. Still, open GLBTQ respondents may differ from straight respondents more than closeted GLBTQs do; if so, our analysis may over-state GLBTQ-heterosexual differences.

In the first section, using 2007 data, we create three dummy variables from responses to the question: "What career goals do you hope to attain within three years of graduation?" Respondents could choose up to 3 of 15 items. We create dummy variables for the 26 percent who listed "Contribute to society" (altruistic), the 29 percent who listed "Build a sound financial 
base" (extrinsically motivated), and the 60 percent who said "Balance a personal life and career" (less career-directed). The other twelve items were not likely to affect choice of sector. We begin with simple cross-tabulations of sex/sexual orientation, preferred sector, and career goals to test whether GLBTQs are more likely to choose the public and nonprofit sectors and to be more altruistic than heterosexuals. We then run a multinomial logit with preferred sector as the dependent variable. Our key independent variables are dummy variables distinguishing GBTQ men, GLBTQ women, and straight women from straight men (the reference group). We control for minority and disability status, age, year in school, type of degree, major field of study, and grade point average (GPA). We use linear terms for year in school and GPA and both linear and squared terms for age. We use 6 dummy variables for type of degree and 8 dummy variables for major.

We use the private sector as the base category for the multinomial logit model, so the coefficients represent changes in the log-odds of preferring public or nonprofit sector jobs or starting one's own business over private sector jobs from a one-unit increase in the independent variable. Changes in the log-odds of preferring the public over the nonprofit sector are the public coefficient minus the nonprofit coefficient. To make this a bit clearer, we translate the logit coefficients into probability changes, holding the gender/sexual orientation variables at zero and all other variables at their means; this means that the base probabilities are the probabilities of preferring each sector for a heterosexual man with the mean characteristics of the data set. The same logit coefficients translate into different probability changes at different base probabilities, so these probability changes are indicative rather than definitive. 
For the second section, we use a much fuller set of work values given as responses to the question: "When considering full-time employment with an organization immediately following graduation, please rate the importance of the following in your decision making." Both surveys have respondents rate 15 identical items ${ }^{2}$ on either a five-point scale (from "Not at all important" to "Essential" in 2007) or on a four-point scale (from "Not at all influential" to "Very influential" in 2010). We put both on four-point scales by combining the bottom two ranks ("Not at all important" and "Not important") in 2007, yielding similar distributions on the 15 items for the two years. We again run a multinomial logit with preferred sector as the dependent variable and sex/sexual orientation and the 15 work values as the key independent variables. We use the same control variables as in the 2007 multinomial logit, plus a dummy variable for survey year.

To test whether GLBTQs expect to pay a higher penalty for working for government, we run regression analyses with expected salaries as our dependent variables. We run separate regressions for each sex/sexual orientation, with the preferred sector as the key independent variable, plus the same control variables. This also allows us to test whether heterosexual men and women expect to earn less in government and nonprofit organizations than in private firms and to see whether students expect to pay a price for job security and altruistic values, beyond the effects of choice of sector.

Any conclusions we draw must be tentative, as GLBTQ postsecondary students are not representative of GLBTQ Canadians generally, and we cannot be sure how representative this

\footnotetext{
${ }^{2}$ Good health and benefits plan, Good initial salary level, Opportunities for advancement in position, Good variety of work, Organization is a leader in its field, Job security, Interesting work, Opportunity to travel, Work-Life balance, Commitment to social responsibility, Good people to work with, Good people to report to, Good training opportunities/New skills development, Strong commitment to employee diversity, Opportunities to have a personal impact.
} 
sample is of Canadian students. Our sample may over-represent women and under-represent visible minorities and Aboriginals: the percentages in our sample are $64 \%, 18 \%$, and $2 \%$, respectively, whereas 2006 census data for Ontario indicate that $53 \%$ of their college students were women, $72 \%$ were white, and $3 \%$ were Aboriginal (Colleges Ontario 2012, 14, 19). The median age in our sample (23) is a little higher than the median age for all college students (21.8) according to the 2006 census (Dale 2010). We could find no good data on the GLBTQ percentage among postsecondary students to compare our sample to. Representativeness is not as important in studying differences between GLBTQs and heterosexuals as it would be for describing patterns for GLBTQs. As the relationships we find are generally consistent across two very large samples conducted three years apart, we are relatively confident in our conclusions.

\section{FINDINGS}

Preferred sector. As shown in Table 1, heterosexual men were the most likely both to prefer jobs in the private, for-profit sector (65.4\% did so) and to want to start their own businesses (10.3\% wanted to do so). GBTQ men and heterosexual women were about 17.5 percentage points less likely than heterosexual men to prefer to work for a private firm, and GLBTQ women were 30 percentage points less likely than straight men to do so. GBTQ men were nearly 50 percent more likely than heterosexual men to choose public sector careers (33.8\% versus $21.2 \%)$ and more than twice as likely to prefer nonprofit jobs (9.0\% versus $3.1 \%)$, but they were not significantly less likely to want to start their own businesses (we describe differences only if they are statistically significant at the .05 level). Heterosexual women were the most likely to want to work for government, but GLBTQ women were by far the most likely 
to want nonprofit sector careers. In sum, GBTQ men were much more likely than heterosexual men to want both government and nonprofit sector jobs, while GLBTQ women were almost as likely as straight women to want government jobs and much more likely to want to work in the nonprofit sector.

\section{[Table 1 about here]}

Career goals and work values. GLBTQ students also claim more altruistic career goals and work values than heterosexuals do. Heterosexual women are about 10 percentage points more likely than heterosexual men to choose "Contribute to society" as one of their top three career goals for their first job; GLBTQs are 8 percentage points more likely than heterosexuals of the same sex to do so. Similarly, women rate the importance of an employer's commitment to social responsibility and employee diversity higher than men do, and GLBTQs rate them higher than do heterosexuals of the same sex. Women also rate opportunities for a personal impact higher than men do; GLBTQ-straight differences are not statistically significant.

Straight women rate job security and benefits - values frequently associated with government employment - as more important than men do. They also prioritize achieving a balance between their personal lives and careers more highly. GBTQ men, however, do not differ from straight men on these values, and GLBTQ women rate all three as less important than straight women do. Although a majority of all groups choose achieving balance among the top three career goals, straight women are the most likely to do so.

Heterosexual men appear the most extrinsically motivated. They and GBTQ men are the most likely to choose building a sound financial base among their top three early career goals, and women are less likely than men of the same sexual orientation to do so. Straight men rank 
starting pay and advancement opportunities as among the most important factors they would consider in choosing a first job but, somewhat surprisingly, straight women prioritize initial salary even higher and advancement opportunities nearly as highly. GLBTQs rank starting salaries and advancement potential lower than do heterosexuals of the same sex, though the GBTQ-straight male difference on starting salary is not statistically significant.

Choice of sector. The multinomial logit model for 2007 confirms that wanting to contribute to society draws one toward both the public and nonprofit sectors (Table 2). Holding the other variables at their means, a heterosexual man has a $66.5 \%$ probability of wanting to work in the for-profit sector, a $21.0 \%$ chance of wanting a government job, a $2.5 \%$ probability of wanting a nonprofit job, and a $9.9 \%$ chance of wanting to start his own business. Listing "contributing to society" among his top three career goals increases his probability of preferring a public sector job by 13.5 percentage points and his probability of wanting to work in the nonprofit sector by 5.2 percentage points. Rating "building a sound financial base" among his top three career goals somewhat decreases his desire for both public and nonprofit sector jobs, and wanting to achieve work-life balance pushes him weakly toward the public sector and away from nonprofit organizations.

\section{[Table 2 about here]}

Even after controlling for GLBTQs' stronger desire to contribute to society, GLBTQs are 7 or 8 percentage points more likely than comparable heterosexual men to choose the public sector. GBTQ men are nearly twice as likely as comparable heterosexual men to prefer the nonprofit sector, and GLBTQ women are nearly five times as likely to do so. GLBTQs are also more likely than comparable heterosexuals of the same sex to want to start their own 
businesses. Heterosexual women are more likely than comparable GLBTQ women to want government jobs, but less likely to want nonprofit sector jobs.

In the multinomial logit on combined 2007 and 2010 data, with better measures of work values, the desires for job security and good benefits are the values that best predict Canadian students' desire for government jobs (in Table 3, work values are listed in order of their impact on the probability of wanting a government job). A one-point rise in the importance they place on job security and good benefits (on a four-point scale from "not at all influential" to "very influential") increases the probability of preferring a public sector job by 8.5 and 5.3 percentage points, respectively. These desires are more likely to drive students away from than toward the nonprofit sector, however.

\section{[Table 3 about here]}

Desires for an employer's commitment to social responsibility and employee diversity and for the opportunity to have a personal impact all increase preference for both public and nonprofit sector jobs. Raising the importance of social responsibility by one point, for instance, increases the probability of preferring the public and nonprofit sectors by 5.3 and 2.2 percentage points, respectively, though that doubles the probability of choosing the nonprofit sector but only raises the probability of preferring a government job by one-fifth because the base probability of preferring the public sector is so much higher. Monetary desires, on the other hand, push students away from both the public and nonprofit sectors.

Holding all variables at their means, GBTQ men, GLBTQ women, and straight women were each about 9 percentage points more likely than comparable straight men to prefer government jobs. As the raw differences from straight in Table 1 are 12 to 17 percentage 
points, differences on these characteristics and work values explain one-fourth to one-half of the differences in preferences for public sector employment. Holding the other independent variables at their means, GBTQ men, GLBTQ women, and straight women are 2.9, 6.5, and 3.0 percentage points, respectively, more likely than straight men to prefer nonprofit jobs. These are all substantially smaller than the gaps in Table 1 , suggesting that differences on these characteristics may account for up to half of GLBTQs' stronger preference for nonprofit employment.

Expected earnings. Heterosexuals who preferred government or nonprofit work expect to earn less than those headed to the private sector (Table 4). Straight men expect to pay the biggest penalties for working in government (by $6 \%$ at entry and $12 \%$ five years out) and especially for working in the nonprofit sector (by $15 \%$ at first and by $20 \%$ five years later). Straight women expect pay disadvantages in those sectors that are 2 to 4 percentage points smaller. Surprisingly, GBTQ men who prefer either sector do not expect to earn significantly less than GBTQ men who prefer the for-profit sector. Indeed, their point estimates suggest an 8 percent advantage in starting pay if they choose government, which dwindles to a 1 percent penalty after five years. They also appear to expect the same starting pay in the nonprofit and for-profit sectors, though they predict a 14 percent pay penalty in the nonprofit sector after five years. Similarly, GLBTQ women estimate they would start 5 percent higher in the public sector and 4 percent lower in the nonprofit sector than in the private sector, though neither difference is statistically significant. Five years out, they expect to make the most in the forprofit sector, but only the nonprofit sector disadvantage is statistically significant.

\section{[Table 4 about here]}


The other coefficients generally line up with expectations. Those with higher grade point averages, pursuing graduate degrees, and majoring in business, engineering, health sciences, and law expect to earn more (only the first is shown). Students expect to pay small penalties to obtain secure jobs, but they appear to expect that penalty to rise slightly over time. (For straight men, it rises from 1 percent at entry to 3 percent after 5 years). Students wanting to work for organizations committed to social responsibility also expect small penalties (beyond those implied by choosing public or nonprofit sector jobs). Those prioritizing initial pay and advancement opportunities expect to make more both at entry and five years later.

\section{CONCLUSION}

Although gay men are under-represented in U.S. government jobs, we find no evidence that GLBTQs are less likely than heterosexuals to want Canadian government jobs. Indeed, among Canadian students, GLBTQ men are substantially more likely than heterosexual men to list the government as their preferred employer, and GLBTQs are substantially more likely than heterosexuals of the same sex to want nonprofit sector jobs. GLBTQs are also more likely to have the altruistic values that impel people toward government and non-profit work, to list contributing to society as one of their top three early career goals, and to rate employers' commitment to social responsibility and employee diversity highly in assessing first jobs. GLBTQs' strong preference for public and nonprofit careers persists after controlling for their work values, as well as their majors, GPAs, age, and degree program. One reason may be that GLBTQs expect to pay a smaller pay penalty for working in the public and nonprofit sectors.

Altruism and PSM do influence the students' preferred sector, but the patterns may not comfort public administration scholars emphasizing the role of PSM in choosing government 
careers. A desire to contribute to society draws students much more strongly to the nonprofit sector, especially if they don't care that much about starting salaries, advancement opportunities, benefits, and job security. Desires for job security and benefits play much bigger roles in directing them toward government jobs: PSM appears to draw Canadian students to the public sector primarily if they expect government to meet their material needs as well. Despite economists' findings that comparable workers earn more in government than the private sector and that even nonprofit workers do pretty well, Canadian students aren't buying it. Those heading toward those sectors expect to earn less both initially and five years out than do those planning private sector careers. Combining these expectations with the finding that prioritizing starting salary and advancement opportunities leads students to prefer the private, for-profit sector fits well with the public service motivation story. 


\section{REFERENCES}

Allegretto, Sylvia A., and Michelle M. Arthur. 2001. "An Empirical Analysis of Homosexual/Heterosexual Male Earnings Differentials: Unmarried and Unequal?" Industrial and Labor Relations Review no. 54 (3):631-646.

Asher, Martin, and Joel Popkin. 1984. "The Effect of Gender and Race Differentials on PublicPrivate Wage Comparisons: A Study of Postal Workers." Industrial \& Labor Relations Review no. 38 (1):16-25.

Badgett, M.V. Lee. 1995. "The Wage Effects of Sexual Orientation Discrimination." Industrial and Labor Relations Review no. 48 (4):726-739.

- - - 2003. Money, Myths, and Change: The Economic Lives of Lesbians and Gay Men. Chicago: University of Chicago Press.

Badgett, M.V. Lee, and Mary C. King. 1997. "Lesbian and Gay Occupational Strategies." In Homo Economics: Capitalism, Community, and Lesbian and Gay Life, edited by Amy Gluckman and Betsy Reed, 73-86. New York: Routledge.

Bailey, Robert W. 1999. Gay Politics, Urban Politics: Identity and Economics in the Urban Setting. New York: Columbia University Press.

Baldwin, J. Norman. 1991. "Public versus Private Employees: Debunking Stereotypes." Review of Public Personnel Administration no. 11 (1/2):1-27.

Beeby, Dean. 1992. "RCMP Hounded Gay Men: '60s Purge of Federal Civil Service Included Idea of 'Fruit Machine.' " The Toronto Star, April 24, A30.

Bellante, Don, and Albert N. Link. 1981. "Are Public Sector Workers More Risk Averse than Private Sector Workers?" Industrial \& Labor Relations Review no. 34 (3):408-412.

Belman, Dale, and John S. Heywood. 1989. "Government Wage Differentials: A Sample Selection Approach." Applied Economics no. 21 (4):427-439.

Berg, Nathan, and Donald Lien. 2002. "Measuring the Effect of Sexual Orientation on Income: Evidence of Discrimination?" Contemporary Economic Policy no. 20 (4):394-414.

Black, Dan A., Hoda R. Makar, Seth G. Sanders, and Lowell J. Taylor. 2003. "The Effects of Sexual Orientation on Earnings." Industrial and Labor Relations Review no. 56 (3):449-469. 
Black, Dan A., Seth G. Sanders, and Lowell J. Taylor. 2007. "The Economics of Lesbian and Gay Families." Journal of Economic Perspectives no. 21 (2):53-70.

Black, Dan, Gary Gates, Seth Sanders, and Lowell Taylor. 2002. "Why Do Gay Men Live in San Francisco?" Journal of Urban Economics no. 51 (1):54-76.

Blank, Rebecca M. 1985. "An Analysis of Workers' Choice between Employment in the Public and Private Sectors." Industrial \& Labor Relations Review no. 38 (2):211-224.

Carpenter, Christopher S. 2004. "Self-reported Sexual Orientation and Earnings: Evidence from California." Industrial \& Labor Relations Review no. 58 (2):258-271.

- - . 2007. "Revisiting the Income Penalty for Behaviorally Gay Men: Evidence from NHANES III." Labour Economics no. 14 (1):25-34.

- - 2008. "Sexual Orientation, Work, and Income in Canada." Canadian Journal of Economics no. 41 (4):1239-1261.

Christensen, Robert K., and Bradley E. Wright. 2011. "The Effects of Public Service Motivation on Job Choice Decisions: Disentangling the Contributions of Person-Organization Fit and Person-Job Fit." Journal of Public Administration Research and Theory.

Colleges Ontario. 2012. Student and Graduate Profiles.

Crewson, Philip E. 1997. "Public-Service Motivation: Building Empirical Evidence of Incidence and Effect." Journal of Public Administration Research and Theory no. 7 (4):499-518.

Dale, Meghan. Trends in the Age Composition of College and University Students and Graduates 2010. Available from http://www.statcan.gc.ca/pub/81-004-x/2010005/article/11386eng.htm.

Dolan, J. 2000. "The Senior Executive Service: Gender, Attitudes, and Reprsentative Bureaucracy." Jounral of Public Administration Research and Theory no. 10 (3):513-530.

Egan, Patrick J. 2012. "Group Cohesion without Group Mobilization: The Case of Lesbians, Gays, and Bisexuals." British Journal of Political Science no. 42:597-612.

Frank, Robert H. 1996. "What Price the Moral High Ground?" Southern Economic Journal no. 63 (1):1-17.

Goddeeris, John H. 1988. "Compensating Differentials and Self-Selection: An Application to Lawyers." The Journal of Political Economy no. 96 (2):411-428. 
Gyourko, Joseph, and Joseph Tracy. 1988. "An Analysis of Public- and Private-Sector Wages Allowing for Endogenous Choices of Both Government and Union Status." Journal of Labor Economics no. 6 (2):229-253.

Hansmann, Henry B. 1980. "The Role of Nonprofit Enterprise." Yale Law Journal no. 89 (5):835901.

Herek, Gregory M., and John P. Capitanio. 1996. "' Some of My Best Friends": Intergroup Contact, Concealable Stigma, and Heterosexuals' Attitudes Toward Gay Men and Lesbians." Personality and Social Psychology Bulletin no. 22 (4):412-424.

Hertzog, Mark 1996. The Lavender Vote: Lesbians, Gay Men, and Bisexuals in American Electoral Politics. New York: NYU Press.

Hindera, John J. 1993. "Representative Bureaucracy: Further Evidence of Active Representation in the EEOC District Offices." Journal of Public Administration Research and Theory no. 3 (4):415-429.

Hou, Feng, and Simon Coulombe. 2010. "Earnings Gaps for Canadian-Born Visible Minorities in the Public and Private Sectors." Canadian Public Policy no. 36 (1):29-43.

Houston, David J. 2000. "Public-Service Motivation: A Multivariate Test." Journal of Public Administration Research and Theory no. 10 (4):713-728.

Karl, Katherine A., and Cynthia L. Sutton. 1998. "Job Values in Today's Workforce: A Comparison of Public and Private Sector Employees." Public Personnel Management no. 27 (4):515516.

Keiser, Lael R., Vicky M. Wilkins, Kenneth J. Meier, and Catherine A. Holland. 2002. "Lipstick and Logarithms: Gender, Institutional Context, and Representative Bureaucracy." American Political Science Review no. 96 (3):553-564.

Kilpatrick, Franklin P., Milton C. Cummings, and M. Kent. Jennings. 1964. The Image of the Federal Service. Washington, DC: Brookings Institution.

Kinsman, Gary. 1995. "'Character Weaknesses" and "Fruit Machines": Towards an Analysis of The Anti-Homosexual Security Campaign in the Canadian Civil Service." Labour/Le Travail no. 35 (Spring):133-161. 
Leete, Laura. 2001. "Whither the Nonprofit Wage Differential? Estimates from the 1990

Census." Journal of Labor Economics no. 19 (1):136-170.

Lewis, Gregory B. 2010. "Modeling Nonprofit Employment: Why Do So Many Lesbians and Gay Men Work for Nonprofit Organizations?" Administration \& Society no. 42 (6):720-748.

- - . 2011. "The Friends and Family Plan: Contact with Gays and Support for Gay Rights." Policy Studies Journal no. 39 (2):217-238.

Lewis, Gregory B., and Sue A. Frank. 2002. "Who Wants to Work for the Government?" Public Administration Review no. 62 (4):395-404.

Lewis, Gregory B., and Charles W. Gossett. 2008. "Changing Public Opinion on Same-Sex Marriage: The Case of California." Politics and Policy no. 36 (1):4-30.

Lewis, Gregory B., and David W. Pitts. 2011. "Representation of Lesbians and Gay Men in Federal, State, and Local Bureaucracies." Journal of Public Administration Research and Theory no. 21 (1):159-180.

Lewis, Gregory B., Marc A. Rogers, and Kenneth Sherrill. 2011. "Gay, Lesbian, and Bisexual Voters in the 2000 US Presidential Election." Politics \& Policy no. 29 (5):655-677.

Light, Paul C. 2002. Pathways to Nonprofit Excellence. Washington, DC: The Brookings Institution.

Lim, Hong-Hai. 2006. "Representative Bureaucracy: Rethinking Substantive Effects and Active Representation." Public Administration Review no. 66 (2):193-204.

McLeod, Donald W. 1996. Lesbian and Gay Liberation in Canada: A Selected Annotated Chronology, 1964-1975. Toronto: ECW Press/Homewood Books.

Meier, Kenneth J. 1993. "Latinos and Representative Bureaucracy Testing the Thompson and Henderson Hypotheses." Journal of Public Administration Research and Theory no. 3 (4):393-414.

Meier, Kenneth J., and Jill Nicholson-Crotty. 2006. "Gender, Representative Bureaucracy, and Law Enforcement: The Case of Sexual Assault." Public Administration Review no. 66 (6):850-860. 
Meier, Kenneth J., Robert D. Wrinkle, and J.L. Polinard. 1999. "Representative Bureaucracy and Distributional Equity: Addressing the Hard Question." The Journal of Politics no. 61 (04):1025-1039.

Mirvis, Philip H. 1992. "The Quality of Employment in the Nonprofit Sector: An Update on Employee Attitudes in Nonprofits versus Business and Government." Nonprofit Management and Leadership no. 3 (1):23-41.

Mirvis, Philip H., and Edward J. Hackett. 1983. "Work and Work Force Characteristics in the Nonprofit Sector." Monthly Labor Review no. 106:3.

Moore, William J., and John Raisian. 1991. "Government Wage Differentials Revisited." Journal of Labor Research no. 12:13-33.

Moulton, Brent R. 1990. "A Reexamination of the Federal-Private Wage Differential in the United States." Journal of Labor Economics no. 8 (2):270-293.

Mueller, Richard E. 1998. "Public-Private Sector Wage Differentials in Canada: Evidence from Quantile Regressions." Economics Letters no. 60 (2):229-235.

- - . 2000. "Public and Private Sector Wage Differentials in Canada Revisited." Industrial Relations: A Journal of Economy and Society no. 39 (3):375-400.

Newstrom, John W., William E. Reif, and Robert M. Monczka. 1976. "Motivating the Public Employee: Fact vs. Fiction." Public Personnel Management no. 5 (1):67-72.

Nierobisz, Annette, Mark Searl, and Charles Théroux. 2008. "Human Rights Commissions and Public Policy: The Role of the Canadian Human Rights Commission in Advancing Sexual Orientation Equality Rights in Canada." Canadian Public Administration no. 51 (2):239263.

Perloff, Jeffrey M., and Michael L. Wachter. 1984. "Wage Comparability in the US Postal Service." Industrial and Labor Relations Review no. 38 (1):26-35.

Perry, James L., Annie Hondeghem, and Lois Recascino Wise. 2010. "Revisiting the Motivational Bases of Public Service: Twenty Years of Research and an Agenda for the Future." Public Administration Review no. 70 (5):681-690.

Perry, James L., and Lois Recascino Wise. 1990. "The Motivational Bases of Public Service." Public Administration Review no. 50 (3):367-373. 
Pettigrew, Thomas F., and Linda R. Tropp. 2006. "A Meta-Analytic Test of Intergroup Contact Theory." Journal of Personality and Social Psychology no. 90 (5):751-783.

President's Pay Agent. 2011. Report on Locality-based Comparability Payments for the General Schedule. Washington, DC: U.S. Department of Labor, Office of Management and Budget, and Office of Personnel Management,.

Preston, Anne E. 1989. "The Nonprofit Worker in a For-Profit World." Journal of Labor Economics no. 7 (4):438-463.

- - . 1990. "Women in the White-Collar Nonprofit Sector: The Best Option or the Only Option?" The Review of Economics and Statistics no. 72 (4):560-568.

Rainey, Hal G. 1982. "Reward Preferences among Public and Private Managers: In Search of the Service Ethic." The American Review of Public Administration no. 16 (4):288-302.

Robinson, Daniel J., and David Kimmel. 1994. "The Queer Career of Homosexual Security Vetting in Cold War Canada." Canadian Historical Review no. 75 (3):319-345.

Robinson, Svend. 2013. "Wynne's Victory 'a Tremendous Signal of Hope and Empowerment.' " The Globe and Mail, January 28.

Rose-Ackerman, Susan. 1996. "Altruism, Nonprofits, and Economic Theory." Journal of Economic Literature no. 34 (2):701-728.

Ruhm, Christopher J., and Carey Borkoski. 2003. "Compensation in the Nonprofit Sector." Journal of Human Resources no. 38 (4):992-1021.

Selden, Sally Coleman. 1997. The Promise of Representative Bureaucracy: Diversity and Responsiveness in a Government Agency. New York: M. E. Sharpe, Inc.

Sherrill, Kenneth. 1996. "The Political Power of Lesbians, Gays, and Bisexuals." PS: Political Science and Politics no. 29 (3):469-473.

Smith, Sharon P. 1976a. "Pay Differentials between Federal Government and Private Sector Workers." Industrial and Labor Relations Review no. 29 (2):176-97.

Smith, Sharon P. 1976b. "Government Wage Differentials by Sex." Journal of Human Resources no. $11(2): 185-199$.

Steijn, Bram. 2008. "Person-Environment Fit and Public Service Motivation." International Public Management Journal no. 11 (1):13-27. 
Taylor, Jeannette. 2008. "Organizational Influences, Public Service Motivation and Work Outcomes: An Australian Study." International Public Management Journal no. 11 (1):67-88.

Vandenabeele, Wouter. 2008. "Government Calling: Public Service Motivation as an Element in Selecting Government as an Employer of Choice." Public administration no. 86 (4):10891105.

Weisbrod, Burton A. 1983. "Nonprofit and Proprietary Sector Behavior: Wage Differentials among Lawyers." Journal of Labor Economics no. 1 (3):246-263.

Wintemute, Robert. 2003. "Sexual Orientation and the Charter: The Achievement of Formal Legal Equality (1985-2005) and Its Limits." McGill Law Journal no. 49:1143-1180.

Wittmer, Dennis. 1991. "Serving the People or Serving for Pay: Reward Preferences among Government, Hybrid Sector, and Business Managers." Public Productivity \& Management Review no. 14 (4):369-383.

Wright, Bradley E. 2007. "Public Service and Motivation: Does Mission Matter?" Public Administration Review no. 67 (1):54-64. 
TABLE 1. Preferred Sector and Work Values by Sex and Sexual Orientation

\begin{tabular}{|c|c|c|c|c|}
\hline & Straight & GBTQ & LGBTQ & Straight \\
\hline Preferred Sector of Employment & $\underline{\text { Man }}$ & Man & Woman & Woman \\
\hline Private, for-profit sector & 65.4 & $-17.4 * * *$ & $-30.2 * * *$ & $-17.5^{* * *}$ \\
\hline Public sector & 21.2 & $12.6 * * *$ & $14.0^{* * *}$ & $17.0^{* * *}$ \\
\hline Nonprofit sector & 3.1 & $5.9 * * *$ & $17.6 * * *$ & $5.4 * * *$ \\
\hline Start own business & 10.3 & -1.1 & -1.4 & $-4.9 * * *$ \\
\hline Sample size & 19,055 & 739 & 820 & 28,612 \\
\hline
\end{tabular}

\section{Career Goals}

Contribute to society

19.6

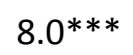

$18.5^{* * *}$

$9.9 * * *$

Build a sound financial base

30.8

2.3

$-5.8^{* *}$

$-2.5^{* * *}$

Balance personal life and career

51.8

3.5

$5.3^{*}$

$12.3^{* * *}$

Sample size

12,642

445

529

19,764

\section{$\underline{\text { Work Values }}$}

Commitment to social responsibility

2.81

$0.17^{* * *}$

$0.41 * * *$

$0.29 * * *$

Strong commitment to employee diversity

2.51

$0.36^{* * *}$

$0.46^{* * *}$

$0.33 * * *$

Opportunities to have a personal impact

3.05

0.06

$0.22^{* * *}$

$0.18 * * *$

Job security

3.17

0.00

$0.08 *$

$0.24 * * *$

Good health and benefits plan

3.14

0.03

$0.15^{* * *}$

$0.27^{* * *}$

Work-Life balance

3.32

$-0.01$

$0.09 * *$

$0.21 * * *$

Opportunities for advancement

3.41

$-0.08 * *$

$-0.25^{* *}$

$-0.03 * * *$

Good initial salary level

3.24

$-0.03$

$-0.06 *$

$0.08^{* * *}$ 


\section{Personal Characteristics}

Age
Aboriginal
Visible minority
Year of study
Master's degree
Doctoral degree
Grade point average

23.9

0.2

0.1

$-0.3 * * *$

1.2

$2.3^{* * *}$

$2.3^{* * *}$

$0.5^{* * *}$

21.4

$-2.6$

$-10.5^{* * *}$

$-3.9 * * *$

2.7

0.0

0.0

0.0

8.1

$-0.1$

$2.0 *$

0.4

4.4

0.2

$-1.2$

$-1.6 * * *$

3.34

$0.05^{* *}$

$0.08^{* * *}$

$0.05 * * *$ 
Table 2. Multinomial Logit Model for Sector Preference, 2007

Private $\begin{array}{ccc}\text { Public } & \text { Nonprofit } & \text { Own Business } \\ \text { Logit Probability } & \text { Logit Probability Logit Probability }\end{array}$
Coefficient

\begin{tabular}{|c|c|c|c|c|c|c|c|}
\hline Base probability & 66.5 & & 21.0 & & 2.5 & & 9.9 \\
\hline $\begin{array}{l}\text { Contribute to } \\
\text { society }\end{array}$ & -18.1 & $\begin{array}{l}0.86^{* * *} \\
(24.87)\end{array}$ & 13.5 & $\begin{array}{l}1.67^{* * *} \\
(29.37)\end{array}$ & 5.2 & $\begin{array}{l}0.24^{* * *} \\
(3.95)\end{array}$ & -0.6 \\
\hline $\begin{array}{l}\text { Build a sound } \\
\text { financial base }\end{array}$ & 6.5 & $\begin{array}{l}-0.22^{* * *} \\
(-6.82)\end{array}$ & -2.5 & $\begin{array}{l}-0.87^{* * *} \\
(-11.80)\end{array}$ & -1.7 & $\begin{array}{l}-0.35^{* * *} \\
(-6.19)\end{array}$ & -2.3 \\
\hline $\begin{array}{l}\text { Balance personal } \\
\text { life and career }\end{array}$ & 1.1 & $\begin{array}{l}0.12^{* * *} \\
(3.82)\end{array}$ & 2.8 & $\begin{array}{l}-0.27^{* * *} \\
(-4.88)\end{array}$ & -0.7 & $\begin{array}{l}-0.33 * * * \\
(-6.73)\end{array}$ & -3.2 \\
\hline GBTQ man & -13.0 & $\begin{array}{l}0.54^{* * *} \\
(4.10)\end{array}$ & 8.1 & $\begin{array}{l}0.86^{* * *} \\
(3.72)\end{array}$ & 2.3 & $\begin{array}{l}0.45^{*} \\
(2.50)\end{array}$ & 2.6 \\
\hline GLBTQ woman & -17.0 & $\begin{array}{l}0.60^{* * *} \\
(4.74)\end{array}$ & 7.5 & $\begin{array}{l}1.84^{* * *} \\
(11.46)\end{array}$ & 9.4 & $\begin{array}{l}0.30 \\
(1.60)\end{array}$ & -0.1 \\
\hline Straight woman & -11.1 & $\begin{array}{l}0.65^{* * *} \\
(19.05)\end{array}$ & 12.5 & $\begin{array}{l}0.93^{* * *} \\
(13.32)\end{array}$ & 2.8 & $\begin{array}{l}-0.35^{* * *} \\
(-6.85)\end{array}$ & -4.1 \\
\hline
\end{tabular}

Observations: 25,879 
Base probabilities indicate that a heterosexual man with mean values on the other variables (intervallevel measures for age, age-squared, year of study, and grade point average, and dummy variables for aboriginals, visible minorities, people with disabilities, major, and degree program) has a $66.5 \%$ chance of preferring to work in the private, for-profit sector, a $21.0 \%$ chance of wanting a government job, a $2.5 \%$ probability of wanting to work for a nonprofit, and a $9.9 \%$ chance of wanting to start his own business. 
Table 3. Multinomial Logit Model for Sector Preference, 2007 and 2010

Private $\begin{array}{ccc}\text { Public } & \text { Nonprofit } & \text { Own Business } \\ \text { Logit Probability } & \text { Logit Probability Logit Probability }\end{array}$
Coefficient

\begin{tabular}{|c|c|c|c|c|c|c|c|}
\hline Base probability & 61.2 & & 25.8 & & 2.2 & & 10.8 \\
\hline GLBTQ man & -9.9 & $\begin{array}{l}0.49 * * * \\
(4.42)\end{array}$ & 9.5 & $\begin{array}{l}1.02^{* * *} \\
(5.78)\end{array}$ & 2.9 & $\begin{array}{l}-0.08 \\
(-0.46)\end{array}$ & -2.4 \\
\hline GLBTQ woman & -15.4 & $\begin{array}{l}0.60^{* * *} \\
(5.19)\end{array}$ & 9.6 & $\begin{array}{l}1.68^{* * *} \\
(11.08)\end{array}$ & 6.5 & $\begin{array}{l}0.22 \\
(1.31)\end{array}$ & -0.7 \\
\hline Straight woman & -6.5 & $\begin{array}{l}0.40^{* * *} \\
(12.80)\end{array}$ & 8.7 & $\begin{array}{l}0.97^{* * *} \\
(15.11)\end{array}$ & 3.0 & $\begin{array}{l}-0.54^{* * *} \\
(-11.06)\end{array}$ & -6.5 \\
\hline Work Values & & & & & & & \\
\hline Job security & -4.1 & $\begin{array}{l}0.40^{* * *} \\
(16.61)\end{array}$ & 8.5 & $\begin{array}{l}-0.22^{* * *} \\
(-5.83)\end{array}$ & -0.6 & $\begin{array}{l}-0.29 * * * \\
(-8.61)\end{array}$ & -3.8 \\
\hline $\begin{array}{l}\text { Commitment to } \\
\text { social responsibility }\end{array}$ & -7.5 & $\begin{array}{l}0.33^{* * *} \\
(15.84)\end{array}$ & 5.3 & $\begin{array}{l}1.11^{* * *} \\
(26.12)\end{array}$ & 2.2 & $\begin{array}{l}0.12^{* * *} \\
(3.83)\end{array}$ & 0.0 \\
\hline $\begin{array}{l}\text { Good health and } \\
\text { benefits plan }\end{array}$ & -3.6 & $\begin{array}{l}0.30^{* * *} \\
(12.76)\end{array}$ & 6.1 & $\begin{array}{l}-0.06 \\
(-1.48)\end{array}$ & -0.2 & $\begin{array}{l}-0.16^{* * *} \\
(-4.65)\end{array}$ & -2.3 \\
\hline $\begin{array}{l}\text { Opportunities to } \\
\text { have a personal imf }\end{array}$ & $\begin{array}{l}-5.5 \\
\text { ppact }\end{array}$ & $\begin{array}{l}0.19^{* * *} \\
(8.67)\end{array}$ & 2.4 & $\begin{array}{l}0.41^{* * *} \\
(10.16)\end{array}$ & 0.7 & $\begin{array}{l}0.31^{* * *} \\
(9.06)\end{array}$ & 2.4 \\
\hline $\begin{array}{l}\text { Strong commitment } \\
\text { to employee diversi }\end{array}$ & -0.7 & $\begin{array}{l}0.04^{*} \\
(2.02)\end{array}$ & 0.7 & $\begin{array}{l}0.09 * \\
(2.56)\end{array}$ & 0.2 & $\begin{array}{l}-0.00 \\
(-0.02)\end{array}$ & -0.2 \\
\hline Interesting work & -1.4 & $\begin{array}{l}0.04 \\
(1.58)\end{array}$ & 0.4 & $\begin{array}{l}0.17^{* * *} \\
(3.68)\end{array}$ & 0.3 & $\begin{array}{l}0.09 * * \\
(2.26)\end{array}$ & 0.7 \\
\hline
\end{tabular}




\begin{tabular}{|c|c|c|c|c|c|c|c|}
\hline Work-Life balance & -1.9 & $\begin{array}{l}0.01 \\
(0.55)\end{array}$ & -0.5 & $\begin{array}{l}0.08 \\
(1.82)\end{array}$ & 0.1 & $\begin{array}{l}0.23 * * * \\
(6.57)\end{array}$ & 2.2 \\
\hline Good training & 2.0 & $-0.05^{*}$ & -0.4 & $-0.21 * * *$ & -0.4 & $-0.14 * * *$ & -1.2 \\
\hline opportunities & & $(-2.01)$ & & $(-4.70)$ & & $(-3.80)$ & \\
\hline Good variety of work & 0.5 & $\begin{array}{l}-0.06 * * \\
(-2.38)\end{array}$ & -1.2 & $\begin{array}{l}-0.01 \\
(-0.34)\end{array}$ & 0.0 & $\begin{array}{c}0.06 \\
(1.07)\end{array}$ & 0.7 \\
\hline Opportunity to travel & 1.6 & $\begin{array}{l}-0.13^{* * *} \\
(-8.17)\end{array}$ & -2.6 & $\begin{array}{l}0.18^{* * *} \\
(6.56)\end{array}$ & 0.5 & $\begin{array}{c}0.02 \\
(0.91)\end{array}$ & 0.5 \\
\hline Good initial salary & 1.5 & $\begin{array}{l}-0.12 * * * \\
(-5.07)\end{array}$ & -2.3 & $\begin{array}{l}-0.46^{* * *} \\
(-11.79)\end{array}$ & -1.0 & $\begin{array}{l}0.15^{* * *} \\
(3.95)\end{array}$ & 1.8 \\
\hline $\begin{array}{l}\text { Good people } \\
\text { to report to }\end{array}$ & 2.9 & $\begin{array}{l}-0.13^{* * *} \\
(-4.71)\end{array}$ & -2.2 & $\begin{array}{l}-0.19 * * * \\
(-3.98)\end{array}$ & -0.3 & $\begin{array}{l}-0.08 * * \\
(-1.99)\end{array}$ & -0.4 \\
\hline $\begin{array}{l}\text { Good people } \\
\text { to work with }\end{array}$ & 3.0 & $\begin{array}{l}-0.17 * * * \\
(-6.17)\end{array}$ & -3.2 & $\begin{array}{l}-0.02 \\
(-0.30)\end{array}$ & 0.1 & $\begin{array}{l}-0.03 \\
(-0.78)\end{array}$ & 0.2 \\
\hline $\begin{array}{l}\text { Organization is a } \\
\text { leader in its field }\end{array}$ & 4.1 & $\begin{array}{l}-0.22^{* * *} \\
(-10.94)\end{array}$ & -3.9 & $\begin{array}{l}-0.28 * * * \\
(-8.13)\end{array}$ & -0.5 & $\begin{array}{l}-0.05 \\
(-1.48)\end{array}$ & 0.2 \\
\hline $\begin{array}{l}\text { Opportunities for } \\
\text { advancement }\end{array}$ & 6.8 & $\begin{array}{l}-0.31 * * * \\
(-13.38)\end{array}$ & -5.2 & $\begin{array}{l}-0.56^{* * *} \\
(-14.61)\end{array}$ & -1.0 & $\begin{array}{l}-0.18^{* * *} \\
(-4.78)\end{array}$ & -0.7 \\
\hline
\end{tabular}

Models also control for minority status, age, year of study, degree type, survey year, and major field of study. 
Table 4. Regression Model for Salary at Start and after Five Years, by Sex and Sexual Orientation

\begin{tabular}{|c|c|c|c|c|}
\hline & $\begin{array}{c}\text { Straight } \\
\text { Man }\end{array}$ & $\begin{array}{c}\text { GLBTQ } \\
\text { Man }\end{array}$ & $\begin{array}{l}\text { GLBTQ } \\
\text { Woman }\end{array}$ & $\begin{array}{l}\text { Straight } \\
\text { Woman }\end{array}$ \\
\hline \multicolumn{5}{|l|}{ Initial base salary } \\
\hline Prefers government & $\begin{array}{c}-0.06 * * * \\
(5.13)\end{array}$ & $\begin{array}{c}0.08 \\
(1.46)\end{array}$ & $\begin{array}{c}0.05 \\
(0.93)\end{array}$ & $\begin{array}{c}-0.02 * * \\
(2.74)\end{array}$ \\
\hline Prefers nonprofit & $\begin{array}{c}-0.15^{* * *} \\
(5.98)\end{array}$ & $\begin{array}{l}-0.00 \\
(0.00)\end{array}$ & $\begin{array}{l}-0.04 \\
(0.61)\end{array}$ & $\begin{array}{c}-0.13^{* * *} \\
(9.23)\end{array}$ \\
\hline Grade point average & $0.07^{* * *}$ & $0.09 *$ & 0.08 & $0.06^{* * *}$ \\
\hline Work Values & & & & \\
\hline Job security & $-0.01 *$ & -0.05 & -0.02 & $-0.01 *$ \\
\hline Good health and benefits plan & 0.01 & 0.03 & $0.07 *$ & $0.03 * * *$ \\
\hline Commitment to social responsibility & $-0.02 * *$ & -0.03 & 0.01 & 0.00 \\
\hline Strong commitment to employee diversity & -0.01 & -0.00 & $-0.06 *$ & -0.01 \\
\hline Opportunities to have a personal impact & 0.00 & -0.03 & -0.00 & 0.00 \\
\hline Good initial salary level & $0.08 * * *$ & $0.10 * *$ & $0.09 *$ & $0.06 * * *$ \\
\hline Opportunities for advancement & $0.02 * * *$ & 0.07 & $0.08^{*}$ & 0.01 \\
\hline Observations & 7,074 & 253 & 258 & 10,009 \\
\hline R-squared & 0.21 & 0.45 & 0.43 & 0.17 \\
\hline
\end{tabular}

Base salary after five years 
Prefers government

Prefers nonprofit

Grade point average

Work Values

Job security

Good health and benefits plan

Commitment to social responsibility

Strong commitment to employee diversity

Opportunities to have a personal impact

Good initial salary level

Opportunities for advancement
$-0.12^{* * *} \quad-0.01$

$(-0.23)$

$-0.20 * * *$

$-0.14$

$(-6.98)$

$(-1.46)$

$0.08 * * * \quad-0.00$

0.03

$0.04 * * *$

$(-1.41)$

$(-11.03)$

$-0.31 * * *$

$(-4.16)$

$(-11.56)$

$-0.17 * * *$

$\begin{array}{llll}-0.03^{* * *} & -0.08^{*} & -0.07 & -0.02 * * * \\ -0.01 & 0.01 & 0.05 & 0.01 *\end{array}$

$-0.02 * * *$

$-0.01$

0.02

$-0.00$

$-0.00$

$-0.05$

$-0.06$

$-0.00$

$0.01^{*} \quad-0.00$

$-0.03$

0.01*

$$
0.06 * * *
$$

$0.08 *$

0.04

$0.05^{* * *}$

$0.03 * * *$

$0.11^{* *}$

0.09*

$0.04^{* * *}$

\begin{tabular}{|c|c|c|c|c|}
\hline Observations & 6,991 & 254 & 251 & 9,860 \\
\hline R-squared & 0.18 & 0.48 & 0.44 & 0.14 \\
\hline \multicolumn{5}{|c|}{${ }^{*}$ Significant at .05 level; ${ }^{* *}$ Significant at .01 level; $* * *$ Significant at .001 level; } \\
\hline
\end{tabular}

